\title{
Microbial study related with the arsenic hydrogeochemistry of the Xichú River in Guanajuato, Mexico
}

\author{
U.E. Rodríguez Castrejón, A.H. Serafín Muñoz, C. Cano Canchola \& A. Álvarez Vargas \\ Departamento de Biología, División de Ciencias Naturales y Exactas, Universidad de Guanajuato, Campus \\ Guanajuato, México
}

\begin{abstract}
Microorganisms play an important role in many surface and near-surface geochemical environments. Partial physicochemical characterization of Xichu River waters showed high concentrations of As $\left(98 \mathrm{~g} \mathrm{~L} \mathrm{~L}^{-1}\right)$ in the zone of the "Aurora" mine probably due to arsenic release into the environment through metal sulfide oxidation. Several microorganisms strains resistant or tolerant to $20 \mathrm{mM}$ of As(III) or As(V) were isolated from the river water, sediments and/or biofilms. The microorganisms likely interact with arsenic through mechanisms such as sorption, mobilization, precipitation and redox reactions, understanding of which may facilitate the development of new bio-treatments.
\end{abstract}

\section{INTRODUCTION}

Arsenic (As) is toxic to humans and other organisms. Its mobility in the environment occurs through natural processes, for instance, weathering reactions, biological activity and volcanic emissions, as well as through anthropogenic processes (Hu \& Gao, 2008). Arsenic can affect exploitation of water, agricultural development and sustainable use of soil, directly affecting socioeconomic growth in affected areas (Litter et al., 2009).

Environmental geochemistry includes a consideration of geological, mineralogical and chemical processes that introduce and control concentrations, reactions and mobility of potentially toxic elements (PTE) in the environment (Hudson et al., 2011). Microorganisms interact with the arsenic through mechanisms such as adsorption, redox reactions and precipitation, and may play a major role in determining the rate of releasing of arsenic in geochemical environments.

\section{METHODS/EXPERIMENTAL}

\section{$2.1 \quad$ Water samples processing}

Water samples were collected from the Xichú river, which contains high concentrations of arsenic as well as tons of tailings from the "Aurora" mine. The sample site is located inside the "Sierra Gorda of Guanajuato", a Mex. Biosphere and federal natural reserve in the state of Guanajuato, Mexico.

Samples were taken at 7 sites either in April, September or both months: Before Jales (BJ) Jales (J), After Jales (AJ), Entry Jales (EJ), Waterhole (WO), Mixture (M) and Laja River (LR).

In-situ analyses were carried out for: alkalinity, electric conductivity, dissolved oxygen and temperature with a potentiometer (Thermo Scientific). Furthermore, sulfates, sulfides, ferrous ion, nitrate, and nitrites were determined in the laboratory with $\mathrm{HACH}$ equipment. Metals ( $\mathrm{Pb}, \mathrm{Cd}, \mathrm{Zn}, \mathrm{Mn}, \mathrm{Cu})$ and arsenic were determined by atomic absorption spectrometry.

\subsection{Microbiological analysis}

The isolation of microorganisms from the each sample was carried out on nutritive agar (NA) as a growth medium amended with sodium arsenite (As(III)) and sodium arsenate $(\mathrm{As}(\mathrm{V}))$ in increasing concentrations to $20 \mathrm{mM}$ to obtain microorganisms (tolerant or resistant) to both arsenic salts under aerobic or anaerobic conditions. Microorganisms tolerant or resistant to $(\mathrm{As}(\mathrm{III}))$ or $(\mathrm{As}(\mathrm{V}))$ with capacities to grow under aerobic or anaerobic conditions were morphologically characterized for its molecular identification by using comparisons of $16 \mathrm{~S}$ ribosomal gene sequences. Other characterization that will be done is the detection of genes involved with its arsenic interaction.

\section{RESULTS AND DISCUSSION}

\subsection{Water samples}

Water analyses are summarized in Table 1 . The highest arsenic concentration found was $98 \mu \mathrm{g} \mathrm{L}^{-1}$, the lowest $0 \mu \mathrm{g} \mathrm{L}^{-1}$, with the higher values near the "Aurora" mine as reported by Salas (214), and the lower values being found at sampling sites more distant from the "Aurora" mine and also during the summer. These trends reflect a point source discharge diluted with distance (Drahota et al., 2013). 
Table 1. Water Analysis Results. ND = not determined.

\begin{tabular}{|c|c|c|c|c|c|c|c|c|c|c|c|}
\hline \multirow[b]{2}{*}{ Parameters } & \multicolumn{5}{|c|}{ April Samples } & \multicolumn{6}{|c|}{ September Samples } \\
\hline & $A J$ & $J$ & $E J$ & $D J$ & $O A$ & $A J$ & $J$ & $E J$ & $D J$ & $M Z$ & $R L$ \\
\hline $\mathrm{SO}_{4}^{2-} \mathrm{mg} \mathrm{L}^{-1}$ & 110 & 133 & 145 & 160 & 123 & 12.3 & 17.6 & 12 & 15.3 & 24 & 18 \\
\hline $\mathrm{pH}$ & 9.37 & 9.55 & 9.50 & 10.19 & 7.50 & 8.43 & 8.38 & 8.34 & 8.66 & 8.60 & 8.77 \\
\hline $\mathrm{S}^{-2} \mathrm{mg} \mathrm{L}^{-1}$ & 0.00 & 0.00 & 0.00 & 0.00 & 0.00 & 0.09 & 0.15 & 0.14 & 0.10 & 0.14 & 0.07 \\
\hline $\mathrm{EC} \mu \mathrm{S} \mathrm{cm}^{-1}$ & 630 & 957 & 653 & 661 & 647 & 156 & 157 & 157 & 161 & 189 & 231 \\
\hline $\mathrm{DO} \mathrm{mg} \mathrm{L}^{-1}$ & 5.7 & 4.68 & 4.18 & 4.45 & 4.2 & 2.08 & 1.67 & 0.8 & 1.6 & 1.2 & 0.96 \\
\hline $\mathrm{T}\left({ }^{\circ} \mathrm{C}\right)$ & 20.2 & 20.5 & 22.6 & 17.821 .9 & 27.1 & 17.8 & 17.7 & 17.7 & 18.1 & 21.1 & 22.9 \\
\hline AsT $\mu \mathrm{gL}^{-1}$ & 35 & 40 & 50 & 98 & 8.9 & 4 & 5 & 5 & 9 & 3 & 0 \\
\hline $\mathrm{Fe}^{2+} \mathrm{mg} \mathrm{L}^{-1}$ & 0.04 & 0.036 & 0.042 & 0.08 & 0.022 & 0.34 & 0.39 & 0.73 & 0.34 & 0.56 & 0.24 \\
\hline Alk mg CaCO${ }_{3} \mathrm{~L}^{-1}$ & ND & ND & ND & ND & ND & 6 & 7 & 6 & 7 & 9 & 12 \\
\hline $\mathrm{NO}^{-3} \mathrm{mg} \mathrm{L}^{-1}$ & 9.6 & 1.25 & 6.8 & 0.9 & 4.0 & 2.6 & 2.9 & 2.1 & 4.4 & 5.8 & 5.3 \\
\hline
\end{tabular}

\subsection{Microbiology analysis}

We isolated 50 arsenic tolerant strains with different phenotypes: Different Gram, cell morphology, colonial morphology (colors blue, yellow, orange, red and withe), arsenite or arsenate tolerance, specific ability to growth on aerobic or anaerobic conditions. We note that Shakya et al. (2012) has previously reported microorganisms able to tolerate similar concentration of As, viz. $13 \mathrm{mM}$ of arsenate and $10 \mathrm{mM}$ of arsenite.

Strains isolated from water were typically more tolerant of arsenite than those from sediment of arsenate, whilst strains isolated from biofilms had similar reistance to arsenite and arsenate. The fact that the microorganism growed in both species: As (III) and As (V) could be influenced for the physicochemical characteristics in the study zone, where it is even seen as a reducing environment and would favor the present of As (III) in water, the arsenate could be in the sediments. Both species can appears in neutral $\mathrm{pH}$ in oxic and anoxic environments (Nordstrom, 2009).

The importance of having isolated microorganism aerobics and anaerobic facultative that grow in presence of arsenic (III) and (V) perhaps indicate that the bacterial are using some arsenic detoxification mechanism through the arsenite oxidation (Oremland \& Stolz, 2003), these hypothesis is due to that the strains coming from water samples had a better growth in presence of As(III). The presence of As(III) can be maintained in oxygenic water by biological reduction of $\mathrm{As}(\mathrm{V})$ (Santini \& Ward, 2012). The arsenate reduction in neutrals environments of $\mathrm{pH}$ are catalyzed majority by microorganism including production of energy and arsenic detoxification (Huang, 2009).

\section{CONCLUSIONS}

High concentrations of arsenic in the Xichu River during both the spring and summer represent a significant hazard to citizens that live near mining waste or drink the river water.

The discovery of various microorganisms with tolerance to all of $\mathrm{As}(\mathrm{III}), \mathrm{As}(\mathrm{V})$ or both species suggests that both these arsenic species may be present in the natural environment - a hypothesis that could be checked by appropriate speciation analysis. The discovery of four types of microorganism, aerobic and anaerobic strict and facultative, suggests different mechanisms of interaction between microorganisms and environmental arsenic.

\section{ACKNOWLEDGEMENTS}

University of Guanajuato CONACYT (Consejo Nacional de Ciencia y Tecnología).

\section{REFERENCES}

Drahota, P., Nováková, B., Matoušsek, T., Mihaljevič, M., Rohovec J. \& Filippi, M. 2013. Diel variation of arsenic, molybdenum and antimony in a stream draining a natural As geochemical anomaly. Appl. Geochem. 31:84-93.

Hu, Z.C. \& Gao, S. 2008. Upper crustal abundances of trace elements: A revision and update. Chem. Geol. 253: 205-221.

Huang, A.H., Teplitski, M., Rathinasabapathi, B. \& Ma, L. 2009. Characterization of arsenic-resistant bacterial comunities in the rhizosphere of an arsenic hyperaccumulator Peteris vittata L. Can. J. Microbiol. 56(3): 263-46.

Hudson, K.A., Jamieson, H.E. \& Lottermoser, B.G. 2011. Mine wastes: past, present and future. Elements 7(6): 375-380.

Litter, M.I., Armienta, M.A., \& Farías, S.S. 2009. Iberoarsen. Metodologías analíticas para la determinación y especiación de arsénico en aguas y suelos. Argentina: CYTED.

Nordstrom, D. K. 2002. Public health-Worldwide occurrences of arsenic in ground water. Science 296: 2143-2145.

Oremland, R.S. \& Stolz, J.F. 2003. The ecology of arsenic. Science 300: 939-44.

Salas, E.F. 2014. Geoquímica y Mineralogía de Jales en Mina Aurora, Xichú, Guanajuato, México, D. F. Thesis.

Santini, J.M. \& Ward, S.A. (Eds.) 2012. The Metabolism of Arsenite. In: Arsenic in the Environment 5. CRC Press, Boca Raton, Florida, $189 \mathrm{p}$

Shakya, S., Pradhan, B, Smith, I., Shrestha, J. \& Tuladhar, S. 2012. Isoltion and characterization of aerobic culturable arsenic-resistant bacteria from surface water and groundwater of Rautahat District, Nepal. J. Environ. Manag. 95: S20-S25. 